\title{
Redox ratio and optical absorption of polyvalent ions in industrial glasses
}

\author{
W THIEMSORN*, K KEOWKAMNERD, P SUWANNATHADA, H HESSENKEMPER ${ }^{\dagger}$ and \\ S PHANICHAPHANT \\ Faculty of Science, Chiang Mai University, Chiang Mai 50202, Thailand \\ ${ }^{\dagger}$ Institute of Ceramics, Glass and Cement, Freiberg University of Mining and Technology, Leipziger St. 28, 09596 \\ Freiberg, Germany
}

MS received 22 September 2006; revised 13 July 2007

\begin{abstract}
The changes in glass structure and redox ratio, $R$ (reduced ion to oxidized ion) of $\mathrm{Mn}^{2+}-\mathrm{Mn}^{3+}$, $\mathrm{Cu}^{+}-\mathrm{Cu}^{2+}, \mathrm{Cr}^{3+}-\mathrm{Cr}^{6+}, \mathrm{Ni}^{2+}-\mathrm{Ni}^{3+}$ and $\mathrm{Co}^{2+}-\mathrm{Co}^{3+}$ couples and optical absorption due to $\mathrm{Mn}^{3+}, \mathrm{Cu}^{2+}, \mathrm{Cr}^{3+}, \mathrm{Ni}^{2+}$ and $\mathrm{Co}^{2+}$ ions in industrial soda-lime-silica glass were investigated as a function of $\mathrm{Na}_{2} \mathrm{O}$ concentration in the range 11-19 $\mathrm{mol} \%$. With increasing $\mathrm{Na}_{2} \mathrm{O}$ concentration in the experimental glasses, the basicity, expressed as calculated basicity, $\Lambda_{\text {cal }}$, increased. ${ }^{29} \mathrm{Si}$ NMR and X-ray diffraction were used to investigate the structural change in glasses. The NMR spectra showed high non-bridging oxygens (NBOs) when the basicity of glass was increased. The results were interpreted to be due to the tetrahedral networks; $Q^{4}$ species were depolymerized by replacing the bridging oxygens (BOs) with NBOs to $Q^{3}$ species. These results confirmed the shift of broadening peaks of XRD patterns. The redox reactions of the $\mathrm{Mn}^{2+}-\mathrm{Mn}^{3+}, \mathrm{Cu}^{+}-\mathrm{Cu}^{2+}$ and $\mathrm{Cr}^{3+}-\mathrm{Cr}^{6+}$ couples shifted more toward their oxidized ions due to the oxygen partial pressure, $p\left(\mathrm{O}_{2}\right)$, during melting and the oxide ion activity, $a_{\mathrm{O}_{2}}$, increased with increasing glass basicity. These changes caused the redox ratio of these ion couples to decrease. The $\mathrm{Ni}^{2+}-\mathrm{Ni}^{3+}$ and $\mathrm{Co}^{2+}-\mathrm{Co}^{3+}$ couples were assumed to be present only in the $\mathrm{Ni}^{2+}$ and $\mathrm{Co}^{2+}$ ions in these glasses, respectively. The optical absorption bands due to $\mathrm{Mn}^{3+}, \mathrm{Cu}^{2+}, \mathrm{Cr}^{3+}, \mathrm{Ni}^{2+}$ and $\mathrm{Co}^{2+}$ ions were also investigated. Their spectra occurred at constant wavelengths with different optical densities or intensities as a function of glass basicity. The increase in the intensities of the absorption bands of these absorbing ions, except for $\mathrm{Cr}^{3+}$ ion, at the maximum wavelength, depends not only on the ion concentration but also

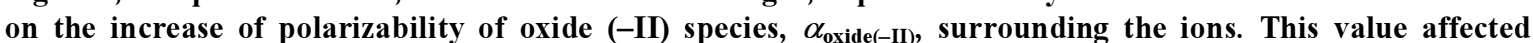
directly the extinction coefficients of the ions, $\varepsilon_{\text {ion }}$. The increase of $\varepsilon_{\text {ion }}$ caused the colour of glasses appearing in high intensity. In the case of $\mathrm{Cr}^{3+}$ ion, the results were reversed such that the lower the concentration, the higher the intensities of colour.
\end{abstract}

Keywords. Calculated glass basicity; optical density; redox ratio; oxide ion activity; polarizability of oxide (-II) species.

\section{Introduction}

Studies of both glass structure and the incorporation of polyvalent elements into the glass are important for determining and controlling the colouring mechanism in different glass systems. For a given condition, the structure of glass depends directly on its composition where it can be represented in terms of glass basicity. Duffy (1996) defined a quantitative model to evaluate the basicity in glass. The optical or calculated basicity, $\Lambda_{\text {cal }}$, may also be calculated from the glass composition by summing terms for each cation in relation to the total number of oxygen ions. Values of $\Lambda_{\text {cal }}$ are obtained using

\footnotetext{
*Author for correspondence (worapong@chiangmai.ac.th)
}

$$
\Lambda_{\mathrm{cal}}=X_{A} \Lambda(A)+X_{B} \Lambda(\mathrm{B})+\ldots,
$$

where $X_{A}, X_{B}, \ldots$ are the molar proportions contributed by the constituent oxides, $A, B, \ldots$ to the total oxide (-II) content of the glass and $\Lambda(A), \Lambda(B), \ldots$ are the optical basicity values of these individual oxides. $\Lambda_{\text {cal }}$ is a useful index to determine the proportion of non-bridging oxygens (NBOs), oxide ion activity, $a_{\mathrm{O} 2-}$ and polarizability as represented by the molar polarizability of oxide (-II) species, $\alpha_{\text {oxide(-II) }}$ (Duffy and Ingram 2002).

Manganese, copper, chromium, nickel and cobalt oxides are widely used for colour formation in glasses. When they are dissolved in a molten glass, the cations distribute into couple states such as $\mathrm{Mn}^{2+}-\mathrm{Mn}^{3+}, \mathrm{Cu}^{+}-\mathrm{Cu}^{2+}, \mathrm{Cr}^{3+}-$ $\mathrm{Cr}^{6+}, \mathrm{Ni}^{2+}-\mathrm{Ni}^{3+}$ and $\mathrm{Co}^{2+}-\mathrm{Co}^{3+}$. The redox reaction of each redox couple can be investigated through the ratio of the reduced to oxidized state called as redox ratio, $R$. The 
change in redox depends on glass composition, melting temperature, imposed oxygen fagucity, the nature and concentration of redox couples and the presence of other redox couples (Schreiber 1986). At a given melting condition, the redox couple shifts towards the oxidized state when modifier ions or glass basicity are increased (Pyare and Nath 1982; Schreiber et al 1994).

When manganese oxide is dissolved in a molten glass, it transforms into $\mathrm{Mn}^{2+}$ and $\mathrm{Mn}^{3+}$ ions and generates purple colour due to $\mathrm{Mn}^{3+}$ ion. In soda-lime-silica glass, the $\mathrm{Mn}^{3+}$ band is centred around $500 \mathrm{~nm}$ in octahedral sites. Copper oxide distributes into $\mathrm{Cu}^{+}$and $\mathrm{Cu}^{2+}$ ions and produces sky blue to green colour due to $\mathrm{Cu}^{2+}$ ion which absorbed the visible spectrum at around $800 \mathrm{~nm}$ in octahedral sites in silicate glasses. Chromium in a silicate glass normally distributes into $\mathrm{Cr}^{3+}$ and $\mathrm{Cr}^{6+}$ ions. The $\mathrm{Cr}^{3+}$ ion generates green colour with three absorption peaks at around 635, 650 and $675 \mathrm{~nm}$ in octahedral sites. In the case of nickel and cobalt oxides dissolved in sodalime-silica glass, which only occurs normally in the $\mathrm{Ni}^{2+}$ and $\mathrm{Co}^{2+}$ ions, produce deep brown and blue colours, respectively. The optical absorption of $\mathrm{Ni}^{2+}$ ion in the tetrahedral sites consists of four bands at around 450, 560, 630 and $930 \mathrm{~nm}$. The absorption bands of $\mathrm{Co}^{2+}$ ions are centred at 540, 590 and $640 \mathrm{~nm}$ in tetrahedral sites (Bamford 1962, 1977).

In a particular silicate glass, the nature and intensity of colour is observed by using the following LambertBeer's equation (Knowles and Burgess 1984)

$$
A_{\lambda_{\max }}=\varepsilon_{\text {ion }} \cdot c_{\text {ion }} \cdot d \text {, }
$$

where $A_{\lambda_{\max }}$ is the absorbance of absorbing ion at its maximum wavelength, $\lambda_{\max }, \varepsilon_{\text {ion }}$ the molar extinction coefficient of absorbing ion ( $1 /$ mole.cm), $c_{\text {ion }}$ the concentration of absorbing ion (mole/l) and $d$ the thickness of the glass sample $(\mathrm{cm})$.

According to (2), the $A_{\lambda_{\max }} / d$ is defined as the absorption density or intensity which depends directly on both the ion concentration (the redox ratio) and the extinction coefficient which are directly related to the structure of glass in a specific melting condition.

This work was designed to study the structural changes in glass, the redox ratio and the absorption colours due to polyvalent ions such as $\mathrm{Mn}^{2+}-\mathrm{Mn}^{3+}, \mathrm{Cu}^{+}-\mathrm{Cu}^{2+}, \mathrm{Cr}^{3+}-\mathrm{Cr}^{6+}$, $\mathrm{Ni}^{2+}-\mathrm{Ni}^{3+}$ and $\mathrm{Co}^{2+}-\mathrm{Co}^{3+}$ couples over a variety of glass compositions, taking into account the effect of network modifier, $\mathrm{Na}_{2} \mathrm{O}$ content, in industrial soda-lime-silica glass at a specific melting condition.

\section{Experimental}

The composition of soda-lime-silica base glass used in the present study was $66-74 \% \mathrm{SiO}_{2}, 11-19 \% \mathrm{Na}_{2} \mathrm{O}, 11 \%$ $\mathrm{CaO}, 3 \% \mathrm{MgO}, 1 \% \mathrm{Al}_{2} \mathrm{O}_{3}$ (in mol\%) including polyvalent metal oxides such as $0.35 \% \mathrm{MnO}, 0 \cdot 15 \% \mathrm{CuO}, 0.07 \%$ $\mathrm{Cr}_{2} \mathrm{O}_{3}, 0 \cdot 15 \% \mathrm{NiO}$ and $0.04 \% \mathrm{CoO}$. Batches yielding $120 \mathrm{~g}$ of glass were made using analytical reagent grade $\mathrm{Na}_{2} \mathrm{CO}_{3}, \mathrm{CaCO}_{3}, \mathrm{Al}_{2} \mathrm{O}_{3}, 4 \mathrm{MgCO}_{3} \cdot \mathrm{Mg}(\mathrm{OH}) 2 \cdot 5 \mathrm{H}_{2} \mathrm{O}, \mathrm{MnO}_{2}$, $\mathrm{CuO}, \mathrm{Cr}_{2} \mathrm{O}_{3}, \mathrm{NiO}$ and $\mathrm{CoO}$ together with calcined Gebaflot $10 \mathrm{~s}$ sand containing $0.012 \mathrm{wt} \% \mathrm{Fe}_{2} \mathrm{O}_{3}$. The homogenized mixtures were melted at an air atmosphere in alumina crucibles using an electric furnace held at $1450^{\circ} \mathrm{C}$ for $4 \mathrm{~h}$. After melting, the glass was fritted by quenching in water. The dried frits were re-melted under the same conditions and were cast onto a steel mould in air at room temperature. The glasses were annealed in an electric furnace at $550^{\circ} \mathrm{C}$ for $15 \mathrm{~min}$ before cooling down to room temperature. The glass was later cut, ground and polished to dimensions required for spectroscopic analysis.

Oxygen partial pressure, $p\left(\mathrm{O}_{2}\right)$, during the melting process was measured using a procedure described by Claes and Decelle (2001). Each glass compositions of $120 \mathrm{~g}$ were melted in alumina and heated to $1450^{\circ} \mathrm{C}$ in an electrical furnace. After the molten glasses were held for $5 \mathrm{~h}$, electrodes were introduced into the melt in such a way that they were positioned in the middle of the sample.

The densities of the polished glass samples were determined by using Archimedes' principle at room temperature using a procedure described in the balance manual (Sartorius YDK 01, YDK 01-0D). Refractive indices of the polished glass samples were determined using Carl Zeiss DDR refractometer.

The compositions and the total $\mathrm{MnO}, \mathrm{CuO}, \mathrm{Cr}_{2} \mathrm{O}_{3}, \mathrm{NiO}$ and $\mathrm{CoO}$ concentrations were determined using atomic emission spectroscopy with inductively coupled plasma, ARL Fisons 3410 ICP. The $\mathrm{Mn}^{3+}$ and $\mathrm{Cu}^{2+}$ ion concentrations were estimated by using their known molar extinction coefficients of soda-lime-silica glasses having similar basicity of glasses in the present work (Paul and Douglas 1995; Claes and Decelle 2001). The $\mathrm{Cr}^{3+}$ concentrations were determined using a procedure described by Matschat et al (2004).

${ }^{29} \mathrm{Si}$ magic angle spinning nuclear magnetic resonance (MAS NMR) spectra were observed with a Bruker advance DPX-300 MHz NMR spectrometer operating at room temperature with 55 magic angle spinning and $300 \mathrm{MHz}$ resonance frequency. All glass samples were powdered and held in $\mathrm{ZrO}_{2}$ sample containers with $4 \mathrm{~mm}$ diameter. The isotropic chemical shifts $\left(\delta_{\text {iso }}\right)$ were referenced to 4,4-dimethyl 4-silapentane sodium sulfonate (DSS).

The X-ray diffraction (XRD) patterns of the glass samples were measured by using a X-ray diffractometer, Philips PW 3710 with $\mathrm{Cu}-\mathrm{K}_{\alpha}$ radiation in the range 10-70 of $2 \theta$.

The UV-vis-NIR absorption spectra of the glass samples were recorded at room temperature using a double beam Perkin Elmer Spectrometer, Lambda 19, with an integration sphere detector and an optical range of 250 $1500 \mathrm{~nm}$. The optical observations used the transmission mode with a scan speed of $120 \mathrm{~nm} / \mathrm{min}$ and a scan inter- 
Table 1. Composition in mol\%, density, refractive index, $n_{\mathrm{D}}$ and calculated glass basicity, $\Lambda_{\text {cal }}$, of the experimental glasses.

\begin{tabular}{|c|c|c|c|c|c|c|c|c|c|c|}
\hline \multirow[b]{2}{*}{ Sample code } & \multicolumn{7}{|c|}{ Mean concentration of oxide in mol\% $( \pm 5 \%)$} & \multirow[b]{2}{*}{ Density $\left(\mathrm{g} / \mathrm{cm}^{3}\right)$} & \multirow[b]{2}{*}{$n_{\mathrm{D}}$} & \multirow[b]{2}{*}{$\Lambda_{\text {cal }}$} \\
\hline & $\mathrm{SiO}_{2}$ & $\mathrm{Na}_{2} \mathrm{O}$ & $\mathrm{CaO}$ & $\mathrm{MgO}$ & $\mathrm{Al}_{2} \mathrm{O}_{3}$ & $\mathrm{TiO}_{2}$ & $\mathrm{~K}_{2} \mathrm{O}$ & & & \\
\hline 1 & $75 \cdot 30$ & $10 \cdot 24$ & $10 \cdot 83$ & $3 \cdot 03$ & 0.43 & 0.02 & $0 \cdot 01$ & $2 \cdot 481$ & $1 \cdot 518$ & 0.557 \\
\hline 2 & 73.23 & 10.96 & $10 \cdot 82$ & 3.03 & 1.78 & 0.02 & 0.01 & 2.497 & 1.524 & 0.562 \\
\hline 3 & 71.03 & $12 \cdot 83$ & $10 \cdot 80$ & $3 \cdot 02$ & $2 \cdot 14$ & 0.02 & $0 \cdot 01$ & $2 \cdot 521$ & 1.527 & $0 \cdot 571$ \\
\hline 4 & $69 \cdot 27$ & $14 \cdot 64$ & $10 \cdot 83$ & $3 \cdot 03$ & $2 \cdot 06$ & 0.02 & 0.01 & 2.536 & 1.528 & 0.579 \\
\hline 5 & $67 \cdot 11$ & $16 \cdot 29$ & $10 \cdot 81$ & 3.03 & 2.59 & 0.02 & 0.01 & $2 \cdot 552$ & 1.530 & 0.587 \\
\hline
\end{tabular}

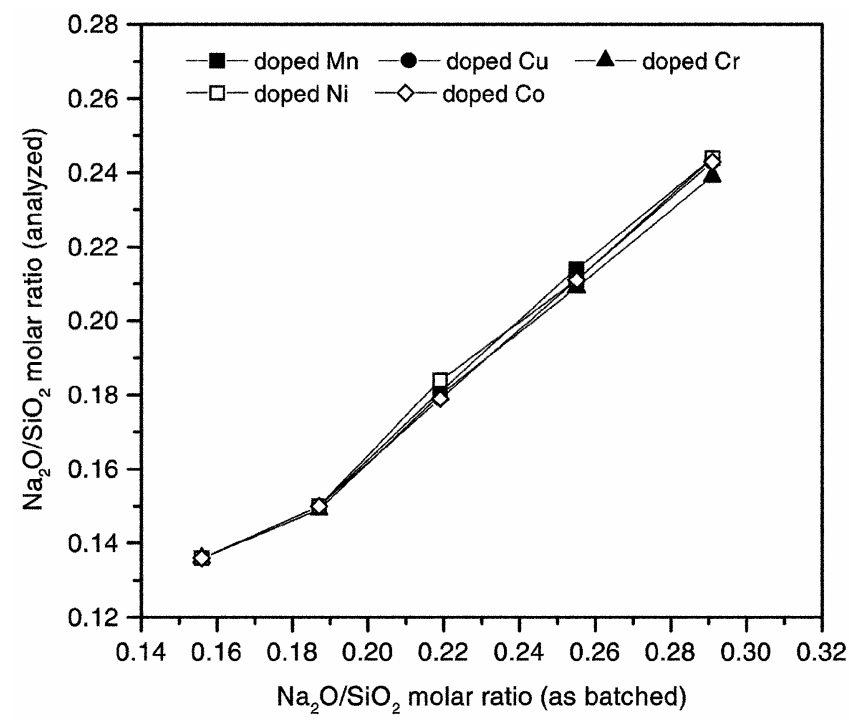

Figure 1. The analysed $\mathrm{Na}_{2} \mathrm{O} / \mathrm{SiO}_{2}$ ratios of the glasses compared with $\mathrm{Na}_{2} \mathrm{O} / \mathrm{SiO}_{2}$ ratio of original compositions. The variation of chemical analysis is within $\pm 6 \%$.

val of $0.5 \mathrm{~nm}$ using plain air as the reference. In order to calculate actual transmission values, the refraction loss of each glass sample was calculated from the refractive index. The corrected transmission values were subsequently converted into absorption (Bamford 1977).

\section{Results and discussion}

\subsection{Compositions and calculated glass basicity, $\Lambda_{c a l}$}

Table 1 shows the concentration of oxide in $\mathrm{mol} \%$ and other important properties such as density, refractive index, $n_{\mathrm{D}}$ and the calculated glass basicity, $\Lambda_{\mathrm{cal}}$, of the glass samples. The chemical compositions in $\mathrm{mol} \%$ of experimented glasses in which the $\mathrm{SiO}_{2}, \mathrm{Na}_{2} \mathrm{O}$ and $\mathrm{Al}_{2} \mathrm{O}_{3}$ contents varied with other components were studied. The concentrations in $\mathrm{mol} \%$ of doped transition oxides were constant: $\mathrm{MnO} 0 \cdot 35, \mathrm{CuO} 0 \cdot 14, \mathrm{Cr}_{2} \mathrm{O}_{3} 0 \cdot 07, \mathrm{NiO} 0 \cdot 14$ and $\mathrm{CoO} 0 \cdot 04$. Note that the small amounts of $\mathrm{TiO}_{2}$ and $\mathrm{K}_{2} \mathrm{O}$ manifestation are primarily due to the impurities associated with the sand used. A slight increase in $\mathrm{Al}_{2} \mathrm{O}_{3}$ con- tent of glass is caused by the dissolution of $\mathrm{Al}_{2} \mathrm{O}_{3}$ from the crucibles. The increased $\mathrm{Al}_{2} \mathrm{O}_{3}$ has a small effect on the basicity of glass because its optical basicity value is low at about 0.6 (Duffy and Ingram 2002). Moreover, study of effect of $\mathrm{Al}_{2} \mathrm{O}_{3}$ on redox equilibrium (Paul 1990) showed that the equilibrium changed little at low $\mathrm{Al}_{2} \mathrm{O}_{3}$ content while a maximum was seen at about $5 \mathrm{~mol} \%$. Thus the redox reactions of polyvalent elements are assumed to be independent on $\mathrm{Al}_{2} \mathrm{O}_{3}$ content.

Figure 1 indicates final $\mathrm{Na}_{2} \mathrm{O} / \mathrm{SiO}_{2}$ ratios that are within $\pm 6 \%$ of the batched $\mathrm{Na}_{2} \mathrm{O} / \mathrm{SiO}_{2}$ ratio of each composition. However, it is assumed that the compositions of glasses are similar when compared with the original compositions.

The densities and refractive indices $\left(n_{\mathrm{D}}\right)$ increased with increasing $\mathrm{Na}_{2} \mathrm{O}(10-16 \mathrm{~mol} \%)$ content in the range $2 \cdot 48-2.55 \mathrm{~g} / \mathrm{cm}^{3}$ and $1.518-1.530$, respectively. $\Lambda_{\text {cal }}$ was obtained by using (1) as shown in table 1 . The results show that the $\Lambda_{\mathrm{cal}}$ values were slightly elevated in the range $0.558-0.587$ as the $\mathrm{Na}_{2} \mathrm{O}$ content increased from $10-16 \mathrm{~mol} \%$. It can be argued that the proportion of nonbridging oxygens (NBOs) in glass structure as well as both the oxide ion activity, $a_{\mathrm{O} 2-}$ and the molar polarizability of oxide (-II) species, $\alpha_{\text {oxide(-II), }}$ increased.

\subsection{NMR studies}

Examples of the ${ }^{29} \mathrm{Si}$ MAS NMR spectra from the base glasses are shown in figure 2 . The spectrum of each glass contained only two isotropic peaks. One peak is centred constantly on the chemical shift, $\delta_{\text {iso }}$ at $-108.5 \mathrm{ppm}$ where it has been identified with silicate tetrahedral possessing four bridging oxygens (BOs) expressed in terms of $Q^{4}$ species. The other peak is varied in the range of $\delta$ iso of -90.4 to $-95.5 \mathrm{ppm}$ for coordinating with three bridging oxygens, $Q^{3}$ species (Jones et al 2001). When glass basicity increased, the $Q^{4}$ peak decreased only in intensity at constant $\delta_{\text {iso }}$ whereas the $Q^{3}$ peak increased both in intensity and in $\delta_{\text {sso. The }} Q^{3}$ chemical shift changes are the indicators to changes in structural parameters such as bond angles and bond lengths including with weaker ionic bonds between NBOs and the alkali cations (Zhang et al 1996; Jones et al 2001).

Table 2 lists the $\mathrm{NBO} /(\mathrm{BO}+\mathrm{NBO})$ ratio, the $\delta_{\text {iso }}$ of $Q^{n}$ species and the relative $Q^{n}$ species for each composition. 
Table 2. ${ }^{29}$ Si MAS NMR parameters for the experimental soda-lime-silica glass with different basicities.

\begin{tabular}{|c|c|c|c|c|c|}
\hline \multirow[b]{2}{*}{$\Lambda_{\mathrm{cal}}$} & \multirow[b]{2}{*}{$\mathrm{NBO} /(\mathrm{BO}+\mathrm{NBO})$} & \multicolumn{2}{|c|}{ Relative $Q^{n}$ species $(\%)( \pm 5 \%)$} & \multicolumn{2}{|c|}{ Chemical shift, $\delta_{\text {iso }}$ of $Q^{n}$ species (ppm) } \\
\hline & & $Q^{4}$ & $Q^{3}$ & $Q^{4}$ & $Q^{3}$ \\
\hline 0.557 & $0 \cdot 274$ & 32 & 68 & -108.5 & -95.5 \\
\hline 0.562 & $0 \cdot 282$ & 30 & 70 & $-108 \cdot 5$ & $-93 \cdot 2$ \\
\hline 0.570 & $0 \cdot 303$ & 24 & 76 & $-108 \cdot 5$ & -92.5 \\
\hline 0.578 & $0 \cdot 330$ & 17 & 83 & $-108 \cdot 5$ & $-91 \cdot 8$ \\
\hline $0 \cdot 586$ & $0 \cdot 353$ & 12 & 88 & $-108 \cdot 5$ & $-90 \cdot 4$ \\
\hline
\end{tabular}

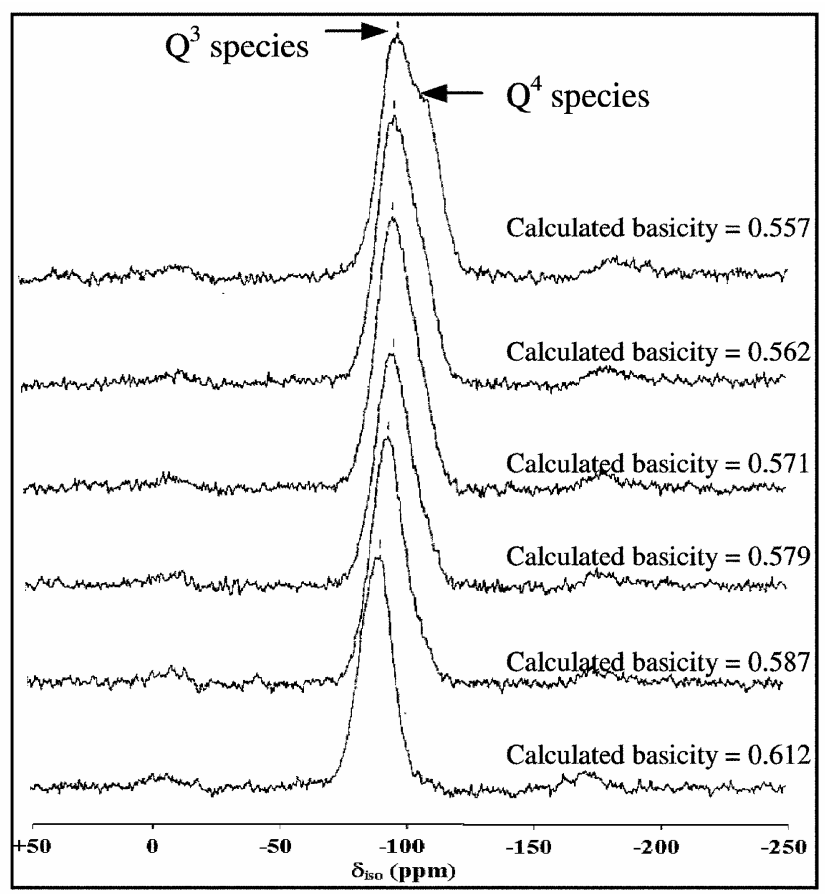

Figure 2. ${ }^{29} \mathrm{Si}$ NMR spectra of the glass having different basicities. The spectra indicate the $Q^{4}$ and $Q^{3}$ species. The change in the chemical shift, $\delta_{\text {so }}$, for the $Q^{3}$ species was observed when the basicity of glass was increased.

The $\mathrm{NBO} /(\mathrm{BO}+\mathrm{NBO})$ ratio was calculated from glass composition as described in the previous work (Jones et al 2001). The relative $Q^{n}$ species were computed by using (3) as mentioned in previous study (Meneau et al 2001),

$$
\frac{\mathrm{NBO}}{\mathrm{BO}+\mathrm{NBO}}=\sum_{n=0}^{4} \frac{8-2 n}{8-n} w\left(Q^{n}\right)
$$

where $w\left(Q^{n}\right)$ is the fraction of the respective $Q$ species, $n$ the number of bridging oxygens.

In all compositions, the $Q^{3}$ species were dominant and increased in the range $68-88 \%$ while that of $Q^{4}$ species decreased from $32-12 \%$ with increasing glass basicity. It can be seen that the silicate tetrahedral networks were depolymerized on replacing BOs with NBOs.

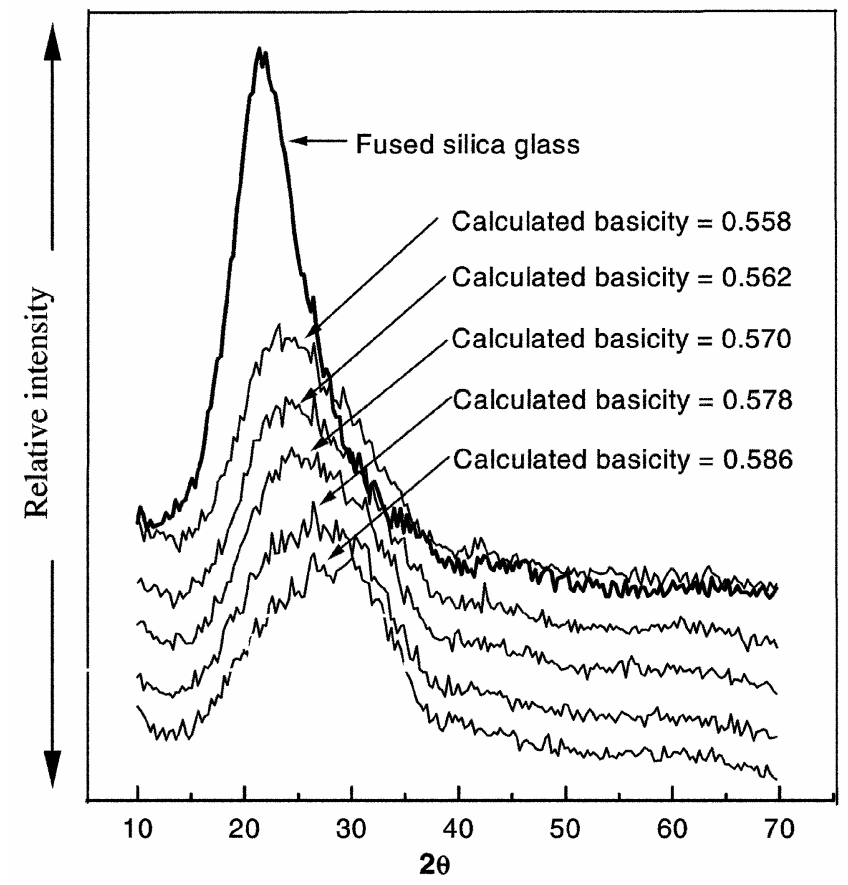

Figure 3. XRD patterns of the glass as a function of glass basicity. Fused silica glass was used as the reference.

\subsection{XRD studies}

Figure 3 shows the experimental XRD patterns of glass with different calculated basicities compared with a fused silica glass used as the reference. It was found that all glasses presented one broad band which could be assigned to completely amorphous phase. A fused silica has no sharp diffraction peak at $21.5(2 \theta)$ angles corresponding to the peak of referred silica glass (Conradt 1997). This peak has been described with only presenting silicate tetrahedral, $Q^{4}$ species. However, a precise comparison between characteristics of this peak and experimental glass peaks has shown a shift to a large angle side and low intensity as well as the peaks expand as a function of increasing basicity. This change can be due to the fact that the $Q^{4}$ species decreased and changed to $Q^{3}$ species by replacing the BOs with NBOs, so this leads to the glass structure development due to high degree of depolymerization. 
Table 3. The redox ion concentrations, redox ratio, $R$, oxygen partial pressure, $p\left(\mathrm{O}_{2}\right)$ and the oxide ion activity, $a_{\mathrm{O} 2-}$ of experimental soda-lime-silica glass with different basicities.

\begin{tabular}{|c|c|c|c|c|c|c|c|}
\hline \multirow[b]{2}{*}{ Sample code } & \multirow[b]{2}{*}{$\Lambda_{\text {cal }}$} & \multirow[b]{2}{*}{$a_{\mathrm{O}^{2-}}\left(\times 10^{-9}\right)$} & \multirow[b]{2}{*}{$\log p\left(\mathrm{O}_{2}\right)(\mathrm{Pa})$} & \multicolumn{3}{|c|}{ Mean concentration of redox ion $(\mathrm{mol} / \mathrm{l})$} & \multirow[b]{2}{*}{ Redox ratio $(R)$} \\
\hline & & & & Total ion & Reduced ion & Oxidized ion & \\
\hline \multicolumn{8}{|c|}{ Doping with Mn } \\
\hline Mn1 & 0.557 & 3.47 & 3.72 & $0 \cdot 137$ & $0 \cdot 129$ & 0.008 & $16 \cdot 13$ \\
\hline $\mathrm{Mn} 2$ & $0 \cdot 562$ & $4 \cdot 50$ & 3.75 & $0 \cdot 137$ & $0 \cdot 126$ & $0 \cdot 011$ & $11 \cdot 45$ \\
\hline $\mathrm{Mn} 3$ & 0.571 & $6 \cdot 23$ & $3 \cdot 83$ & $0 \cdot 137$ & $0 \cdot 126$ & 0.011 & 11.45 \\
\hline Mn4 & 0.579 & $8 \cdot 16$ & $3 \cdot 91$ & $0 \cdot 137$ & $0 \cdot 126$ & $0 \cdot 011$ & 11.45 \\
\hline Mn5 & $0 \cdot 587$ & $10 \cdot 80$ & 3.99 & $0 \cdot 137$ & $0 \cdot 125$ & $0 \cdot 012$ & $10 \cdot 42$ \\
\hline \multicolumn{8}{|c|}{ Doping with $\mathrm{Cu}$} \\
\hline $\mathrm{Cul}$ & $0 \cdot 557$ & 3.47 & $3 \cdot 72$ & $0 \cdot 059$ & $0 \cdot 013$ & $0 \cdot 046$ & $0 \cdot 28$ \\
\hline $\mathrm{Cu} 2$ & $0 \cdot 562$ & $4 \cdot 50$ & 3.75 & $0 \cdot 059$ & $0 \cdot 013$ & $0 \cdot 046$ & $0 \cdot 28$ \\
\hline $\mathrm{Cu} 3$ & $0 \cdot 571$ & $6 \cdot 23$ & $3 \cdot 83$ & $0 \cdot 059$ & $0 \cdot 013$ & $0 \cdot 046$ & $0 \cdot 28$ \\
\hline $\mathrm{Cu} 4$ & $0 \cdot 579$ & $8 \cdot 16$ & $3 \cdot 91$ & $0 \cdot 059$ & $0 \cdot 011$ & $0 \cdot 048$ & $0 \cdot 23$ \\
\hline $\mathrm{Cu} 5$ & $0 \cdot 587$ & $10 \cdot 80$ & 3.99 & 0.059 & $0 \cdot 010$ & $0 \cdot 049$ & $0 \cdot 20$ \\
\hline \multicolumn{8}{|c|}{ Doping with $\mathrm{Cr}$} \\
\hline Cr1 & $0 \cdot 557$ & 3.47 & 3.72 & 0.057 & 0.052 & 0.003 & $17 \cdot 33$ \\
\hline $\mathrm{Cr} 2$ & $0 \cdot 562$ & $4 \cdot 50$ & 3.75 & 0.057 & $0 \cdot 049$ & 0.008 & $6 \cdot 13$ \\
\hline $\mathrm{Cr} 3$ & $0 \cdot 571$ & $6 \cdot 23$ & $3 \cdot 83$ & $0 \cdot 057$ & $0 \cdot 044$ & $0 \cdot 013$ & $3 \cdot 38$ \\
\hline $\mathrm{Cr} 4$ & 0.579 & $8 \cdot 16$ & 3.91 & $0 \cdot 057$ & $0 \cdot 042$ & $0 \cdot 015$ & $2 \cdot 80$ \\
\hline $\mathrm{Cr} 5$ & 0.587 & $10 \cdot 80$ & 3.99 & 0.057 & $0 \cdot 040$ & $0 \cdot 017$ & $2 \cdot 35$ \\
\hline \multicolumn{8}{|c|}{ Doping with $\mathrm{Ni}$} \\
\hline Nil & 0.557 & 3.47 & $3 \cdot 72$ & 0.062 & 0.062 & Absent & - \\
\hline $\mathrm{Ni} 2$ & 0.562 & $4 \cdot 50$ & 3.75 & $0 \cdot 062$ & 0.062 & Absent & - \\
\hline $\mathrm{Ni3}$ & $0 \cdot 571$ & $6 \cdot 23$ & $3 \cdot 83$ & $0 \cdot 062$ & $0 \cdot 062$ & Absent & - \\
\hline $\mathrm{Ni4}$ & 0.579 & $8 \cdot 16$ & $3 \cdot 91$ & $0 \cdot 062$ & $0 \cdot 062$ & Absent & - \\
\hline $\mathrm{Ni5}$ & $0 \cdot 587$ & $10 \cdot 80$ & 3.99 & $0 \cdot 062$ & $0 \cdot 062$ & Absent & - \\
\hline \multicolumn{8}{|c|}{ Doping with Co } \\
\hline Col & 0.557 & 3.47 & 3.72 & 0.016 & 0.016 & Absent & - \\
\hline $\mathrm{Co} 2$ & 0.562 & $4 \cdot 50$ & 3.75 & $0 \cdot 016$ & $0 \cdot 016$ & Absent & - \\
\hline $\mathrm{Co} 3$ & $0 \cdot 571$ & $6 \cdot 23$ & $3 \cdot 83$ & $0 \cdot 016$ & $0 \cdot 016$ & Absent & - \\
\hline $\mathrm{Co} 4$ & 0.579 & $8 \cdot 16$ & $3 \cdot 91$ & $0 \cdot 016$ & 0.016 & Absent & - \\
\hline Co5 & 0.587 & $10 \cdot 80$ & 3.99 & $0 \cdot 016$ & $0 \cdot 016$ & Absent & - \\
\hline
\end{tabular}

\subsection{Investigation of redox ratio, $R$}

Table 3 summarizes the concentrations of each redox couple and the redox ratio, $R$ (reduced to oxidized state) in the experimental glass with different basicities. The results show that manganese, copper and chromium oxides dissolved and appeared in reduced and oxidized states as $\mathrm{Mn}^{2+}-\mathrm{Mn}^{3+}, \mathrm{Cu}^{+}-\mathrm{Cu}^{2+}$ and $\mathrm{Cr}^{3+}-\mathrm{Cr}^{6+}$, respectively in the glasses. Nickel and cobalt oxides were dissolved in glasses, usually as only $\mathrm{Ni}^{2+}$ and $\mathrm{Co}^{2+}$ states. Values of $R$ decreased for manganese, copper and chromium couples at high glass basicity. It means that the $\mathrm{Mn}^{2+}-\mathrm{Mn}^{3+}, \mathrm{Cu}^{+}-$ $\mathrm{Cu}^{2+}$ and $\mathrm{Cr}^{3+}-\mathrm{Cr}^{6+}$ redox reactions shifted more toward their oxidized states with increasing glass basicity. Similar results from previous works were reported (Schreiber et al 1994; Müller-Simon 1996). In order to explain the effect of glass basicity on redox ratio at a given melting condition, the redox reaction can be expressed as

$$
4 \mathrm{MO}_{x(\text { melt })}^{(m-2 x)} \leftrightarrow 4 \mathrm{M}_{(\text {melt })}^{(m-n)+}+(4 x-2 n) \mathrm{O}_{(\text {melt })}^{2-}+n \mathrm{O}_{2(\text { melt })},
$$

where $x$ is the number of oxygens associated with the oxidized redox ion in the melt to form an oxo-anion, $n$ the number of electrons involved in the reduction. In order to apply (4), it must be realized that $\mathrm{MO}_{x(\text { melt })}^{(m-2 x)}$ may only be used instead of the value of $x$ which implies the relative number of oxygen associated with the oxidized ion in the melt glass with respect to the reduced ion. The activity coefficients of redox ions are not available (Schreiber 1986; Müller-Simon 1996). Therefore, the change of redox ratio in (4) depends on oxygen partial pressure, $p\left(\mathrm{O}_{2}\right)$, during melting and oxide ion activity, $a_{\mathrm{O}^{2-}}$.

The oxygen partial pressure in this study was expressed in terms of $\log p\left(\mathrm{O}_{2}\right)$ as shown in table 3. The values of $\log p\left(\mathrm{O}_{2}\right)$ increased in the range 3.72-3.99 $\mathrm{Pa}$ with increasing glass basicity. The reason for this result is that 
the $\mathrm{Mn}^{2+}, \mathrm{Cu}^{+}$and $\mathrm{Cr}^{3+}$ ions are oxidized during melting by dissolved oxygens in the glass melt causing the $\mathrm{Mn}^{3+}$, $\mathrm{Cu}^{2+}$ and $\mathrm{Cr}^{6+}$ ions to increase. Another reason of redox change is due to the change of oxide ion activity, $a_{\mathrm{O}^{2-}}$, with increasing concentration of $\mathrm{Na}_{2} \mathrm{O}$ in glass. According to investigation on the $a_{\mathrm{O}^{2-}}$, in the present work, it was calculated as described by Krämer (1991). The $a_{\mathrm{O}^{2-}}$ increased between 3.40 and $11.30 \times 10^{-9}$ when basicity of glass was increased as shown in table 3 . It means that the

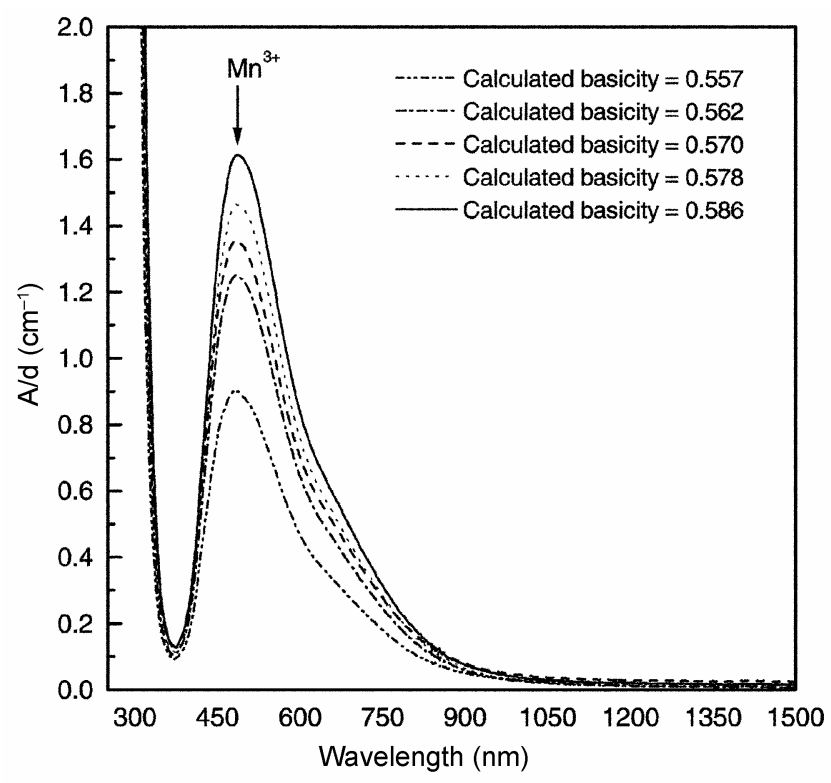

Figure 4. Optical absorption spectra of $\mathrm{Mn}^{3+}$ ion in glass having varying basicities. The $\lambda_{\max }$ of $\mathrm{Mn}^{3+}$ ion $=480 \mathrm{~nm}$.

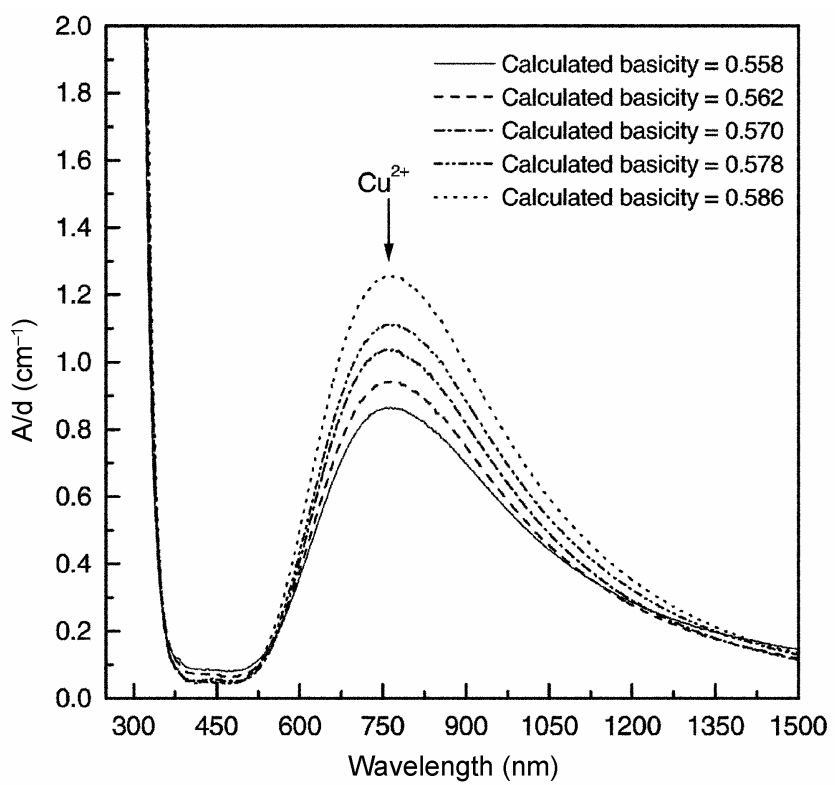

Figure 5. Optical absorption spectra of $\mathrm{Cu}^{2+}$ ion in glass having varying basicities. The $\lambda_{\max }$ of $\mathrm{Cu}^{2+}$ ion $=755 \mathrm{~nm}$. coordinating oxide species, especially on NBOs, have a greater negative charge and donate their charge clouds to redox ions until the ions become unstable. The unstable ions raise a tendency to loose the excess negative charges by going into oxidized states, as a result there is an increase in the $\mathrm{Mn}^{3+}, \mathrm{Cu}^{2+}$ and $\mathrm{Cr}^{6+}$ ions concentration.

\subsection{Optical absorption and colouration}

Figure 4 shows the absorption spectra of the doped manganese with different glass basicities. The spectra due to $\mathrm{Mn}^{3+}$ ion had a unique and broad asymmetric band centred at about $480 \mathrm{~nm}$ in octahedral sites. With increasing glass basicity, the absorption density of $\mathrm{Mn}^{3+}$ band $\left(A / d_{\mathrm{Mn}^{3+}}\right.$ in $\left.\mathrm{cm}^{-1}\right)$ computed by using (2) was increased at almost constant position. Similar results were found in silicate glasses with different alkali contents (Singh et al 2004). The increase of $A / d_{\mathrm{Mn}^{3+}}$ caused the colour intensity of the experimental glasses to change clearly from pale purple to dark purple.

Figure 5 shows the absorption spectra of glass containing copper with different glass basicities. In general, the main broad band of $\mathrm{Cu}^{2+}$ ion was at $755 \mathrm{~nm}$ and near $800 \mathrm{~nm}$ in an octahedral site (Singh et al 2004). The figure shows raising of $A / d_{\mathrm{Cu}^{2+}}$ due to the oxidation of some $\mathrm{Cu}^{+}$ions to $\mathrm{Cu}^{2+}$ ions. The intensity of blue colour slightly increased after increasing the basicity of glass.

In the case of glass containing chromium, the results are presented in figure 6 . The absorption spectra of the green glasses showed three absorption bands due to $\mathrm{Cr}^{3+}$ ion at 640, 655 and $690 \mathrm{~nm}$ in an octahedral site. The

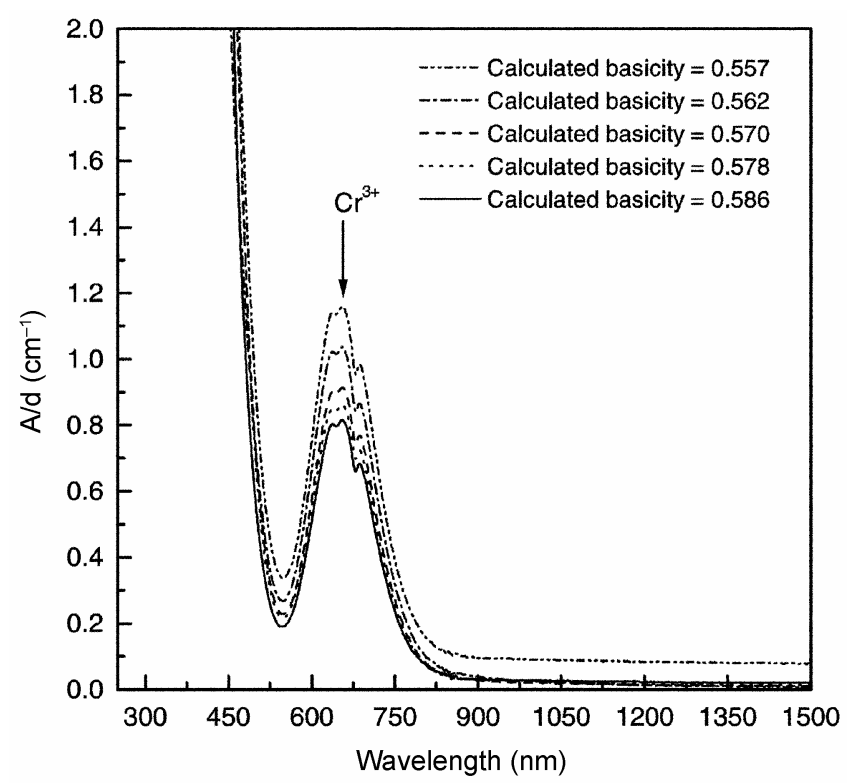

Figure 6. Optical absorption spectra of $\mathrm{Cr}^{3+}$ ion in glass having varying basicities. The $\lambda_{\max }$ of $\mathrm{Cr}^{3+}$ ion $=655 \mathrm{~nm}$. 
$A / d_{\mathrm{Cr}^{3+}}$ at $655 \mathrm{~nm}$ slightly decreased because the $\mathrm{Cr}^{3+}$ ions were oxidized and shifted to the $\mathrm{Cr}^{6+}$ ions causing the intensity of green colour to decrease with increasing glass basicity.

For glass doped with nickel, consistently four absorption bands due to $\mathrm{Ni}^{2+}$ ion were observed at 450, 550, 630 and $980 \mathrm{~nm}$ in tetrahedral sites, as shown in figure 7. All the observed glasses containing nickel were deep brown. Glasses containing cobalt were dark blue. There were no variations in the position of bands with the change in their glass basicity as shown in figure 8 . The spectra of $\mathrm{Co}^{2+}$ ions consist of three absorption bands at 525, 595 and $650 \mathrm{~nm}$ in tetrahedral site, corresponding to the one reported earlier (Bamford 1962). As an incretion of glass basicity, the $\mathrm{Ni}^{2+}$ and $\mathrm{Co}^{2+}$ ion concentrations were constant and assumed to be only one state in the experimental glasses. The results, however, showed the $A / D_{\mathrm{Ni}^{2+}}$ and $A / D_{\mathrm{Co}^{2+}}$ values to increase when the basicity was increased from $0.557-0.587$. This indicates that the $A / d$ of $\mathrm{Ni}^{2+}$ and $\mathrm{Co}^{2+}$ ions are not affected by their concentration but depend directly on glass structure.

The wavelength maxima of $\mathrm{Mn}^{3+}, \mathrm{Cu}^{2+}, \mathrm{Cr}^{3+}, \mathrm{Ni}^{2+}$ and $\mathrm{Co}^{2+}$ ion absorptions coordinated by NBOs were constant. This means that the coordination of these ions, octahedral sites for $\mathrm{Mn}^{3+}, \mathrm{Cu}^{2+}$ and $\mathrm{Cr}^{3+}$ ions and tetrahedral sites for $\mathrm{Ni}^{2+}$ and $\mathrm{Co}^{2+}$ ions, do not change with change in the range of basicity between 0.558 and 0.587 as the $\mathrm{Na}_{2} \mathrm{O}$ content increased from 10-16 mol\%. Moreover, the ligand field strength $(D q)$ for these ions may be presented at high ligand field and also high stabilization energy, and/or is insensitive to given condition in this work (Singh and Kumar 1995; Dawy and Salama 2001).

The colour intensities in glasses depend not only on the absorbing ions through redox changes but also on extinction coefficients of the ion, $\varepsilon_{\text {ion }}$, which relate directly to the structure of glasses. Table 4 and figure 9 show the molar extinction coefficients of each ion at the maximum wavelength which were obtained from absorption spectra through the Lambert-Beer's relation in (2). The $\varepsilon_{\text {ion }}$ values of these ions, except for the $\varepsilon_{\mathrm{Cr}^{3+}}$, shifted toward high values such as $112 \cdot 50-134 \cdot 17,18 \cdot 70-25 \cdot 51,44 \cdot 52-56 \cdot 61$ and 152.50-193.13 1/mole.cm for $\mathrm{Mn}^{3+}, \mathrm{Cu}^{2+}, \mathrm{Ni}^{2+}$ and $\mathrm{Co}^{2+}$ ions, respectively with increasing glass basicity. The $\varepsilon_{\mathrm{Cr}^{3+}}$ value decreased a little in the range of 22.31-20.50 $1 /$ mole.cm. The behaviour of the increased $\varepsilon_{\text {ion }}$ can also be evaluated through structure arguments, especially on the polarizability of the oxide (-II) species, $\alpha_{\text {oxide(-II), su- }}$ rrounding the absorbing ions. The $\alpha_{\text {oxide(-II) }}$ was calculated following the method described by Duffy (2002) and the results are shown in table 4 . The obtained data on the $\alpha_{\text {oxide(-II) }}$ is in agreement with the previous results concerning oxide ion polarizability (Dimitrov and Komatsu 1999; Dawy and Salama 2001; Duffy 2002).

Values of the $\alpha_{\text {oxide(-II) }}$ varied from $1.573-1.608 \AA^{3}$ on increasing glass basicity due to the increase of $\mathrm{Na}_{2} \mathrm{O}$ concentration strongly affecting the electron density of the surrounding oxide (-II) species. It means that the oxide (-II) species polarized their electron cloud to the absorbing ion causing the absorption strength of the ions to increase, as well as, the intensities of colours, especially in the cases of $\mathrm{Ni}^{2+}$ and $\mathrm{Co}^{2+}$ ions in this work.

For the $\varepsilon_{\mathrm{Cr}^{3+}}$ which varied in narrow range, i.e. the green colour intensity of $\mathrm{Cr}^{3+}$ ion may not be strongly affected by glass structure change but depend directly on the $\mathrm{Cr}^{3+}$ which is proportional to the increase of $\mathrm{Na}_{2} \mathrm{O}$ concentration in the glasses.

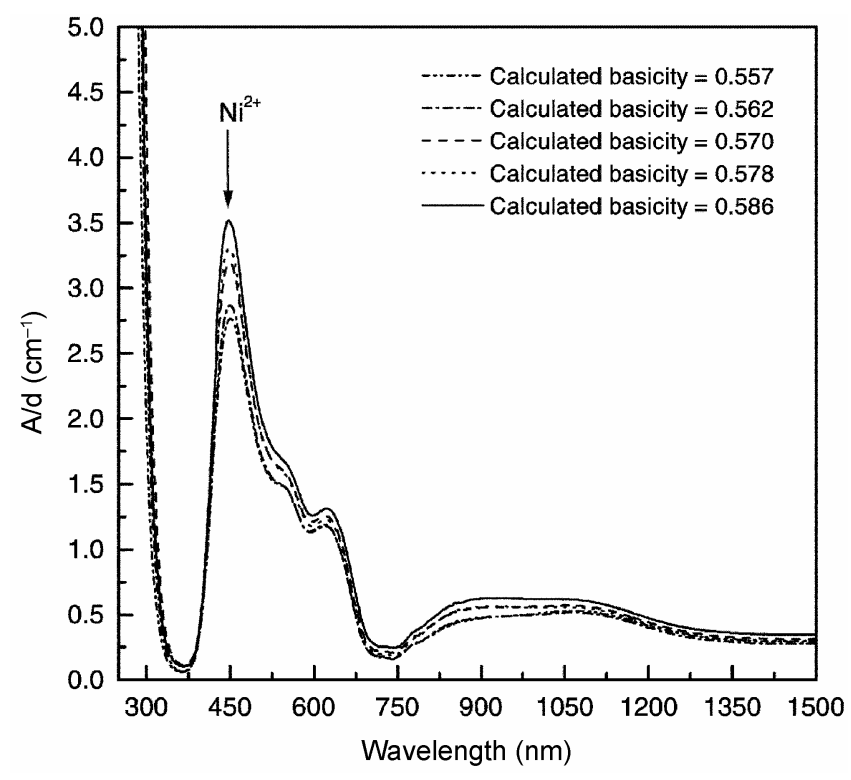

Figure 7. Optical absorption spectra of $\mathrm{Ni}^{2+}$ ion in glass having varying basicities. The $\lambda_{\max }$ of $\mathrm{Ni}^{2+}$ ion $=450 \mathrm{~nm}$.

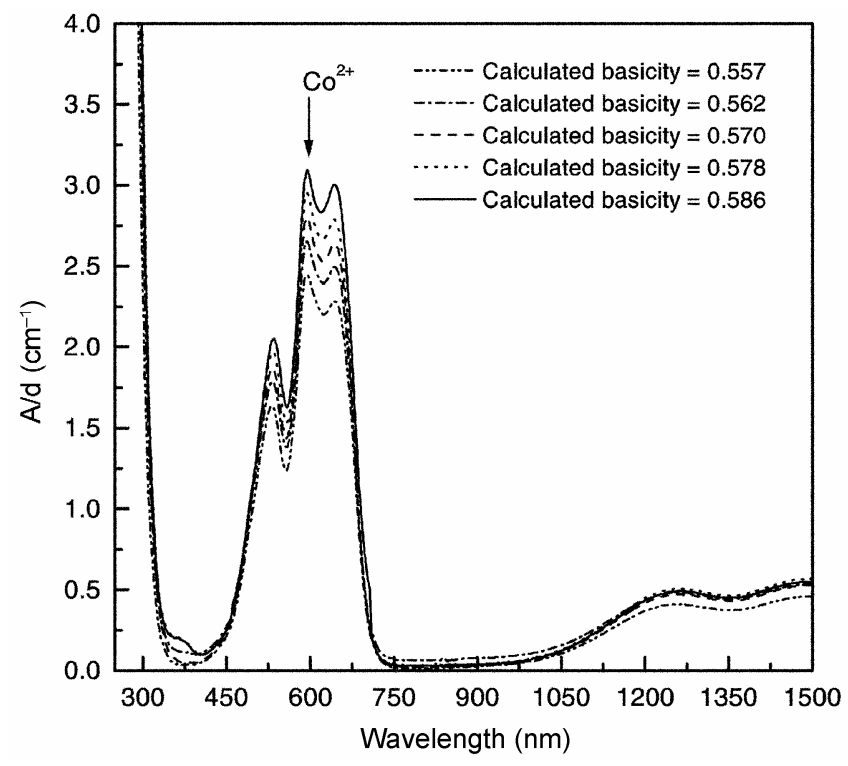

Figure 8. Optical absorption spectra of $\mathrm{Co}^{2+}$ ion in glass having varying basicities. The $\lambda_{\max }$ of $\mathrm{Co}^{2+}$ ion $=595 \mathrm{~nm}$. 
Table 4. The optical absorption data due to $\mathrm{Mn}^{3+}, \mathrm{Cu}^{2+}, \mathrm{Cr}^{3+}, \mathrm{Ni}^{2+}$ and $\mathrm{Co}^{2+}$ ions in experimental soda-lime-silica glass having different basicities.

\begin{tabular}{|c|c|c|c|c|c|}
\hline Sample code & $\Lambda_{\text {cal }}$ & $\alpha_{\text {oxide (-II) }}\left(\AA^{3}\right)$ & Absorbing ion concentration $(\mathrm{mol} / \mathrm{l})$ & $A / d$ at $\lambda_{\max }\left(\mathrm{cm}^{-1}\right)$ & $\varepsilon_{\text {ion }}(1 /$ mole.cm $)$ \\
\hline $\mathrm{Mn}^{3+}$ absorption & & & $\mathrm{Mn}^{3+}$ & at $480 \mathrm{~nm}$ & $\varepsilon_{\mathrm{Mn} 3+}$ \\
\hline Mn1 & $0 \cdot 557$ & 1.573 & $0 \cdot 008$ & $0 \cdot 90$ & $112 \cdot 50$ \\
\hline $\mathrm{Mn} 2$ & $0 \cdot 562$ & $1 \cdot 585$ & $0 \cdot 011$ & 1.25 & $113 \cdot 64$ \\
\hline Mn3 & $0 \cdot 571$ & $1 \cdot 590$ & $0 \cdot 011$ & $1 \cdot 35$ & $122 \cdot 73$ \\
\hline Mn4 & $0 \cdot 579$ & $1 \cdot 599$ & $0 \cdot 011$ & $1 \cdot 46$ & $132 \cdot 73$ \\
\hline Mn5 & $0 \cdot 587$ & $1 \cdot 608$ & $0 \cdot 012$ & $1 \cdot 61$ & $134 \cdot 17$ \\
\hline $\mathrm{Cu}^{2+}$ absorption & & & $\mathrm{Cu}^{2+}$ & at $755 \mathrm{~nm}$ & $\varepsilon_{\mathrm{Cu} 2+}$ \\
\hline $\mathrm{Cul}$ & $0 \cdot 557$ & $1 \cdot 573$ & $0 \cdot 046$ & $0 \cdot 86$ & $18 \cdot 70$ \\
\hline $\mathrm{Cu} 2$ & $0 \cdot 562$ & $1 \cdot 585$ & $0 \cdot 046$ & $0 \cdot 94$ & $20 \cdot 43$ \\
\hline $\mathrm{Cu} 3$ & $0 \cdot 571$ & $1 \cdot 590$ & $0 \cdot 046$ & $1 \cdot 04$ & $22 \cdot 61$ \\
\hline $\mathrm{Cu} 4$ & $0 \cdot 579$ & 1.599 & $0 \cdot 048$ & $1 \cdot 11$ & $23 \cdot 13$ \\
\hline $\mathrm{Cu} 5$ & $0 \cdot 587$ & $1 \cdot 608$ & $0 \cdot 049$ & $1 \cdot 25$ & $25 \cdot 51$ \\
\hline $\mathrm{Cr}^{3+}$ absorption & & & $\mathrm{Cr}^{3+}$ & at $655 \mathrm{~nm}$ & $\varepsilon_{\mathrm{Cr} 3+}$ \\
\hline $\mathrm{Cr} 1$ & $0 \cdot 557$ & $1 \cdot 573$ & $0 \cdot 052$ & $1 \cdot 16$ & $22 \cdot 31$ \\
\hline $\mathrm{Cr} 2$ & $0 \cdot 562$ & $1 \cdot 585$ & 0.049 & $1 \cdot 04$ & $21 \cdot 22$ \\
\hline $\mathrm{Cr} 3$ & $0 \cdot 571$ & $1 \cdot 590$ & $0 \cdot 044$ & 0.91 & $20 \cdot 68$ \\
\hline $\mathrm{Cr} 4$ & $0 \cdot 579$ & 1.599 & $0 \cdot 042$ & $0 \cdot 86$ & $20 \cdot 48$ \\
\hline $\mathrm{Cr} 5$ & $0 \cdot 587$ & $1 \cdot 608$ & $0 \cdot 040$ & $0 \cdot 82$ & $20 \cdot 50$ \\
\hline $\mathrm{Ni}^{2+}$ absorption & & & $\mathrm{Ni}^{2+}$ & at $450 \mathrm{~nm}$ & $\varepsilon_{\mathrm{Ni2}+}$ \\
\hline Nil & 0.557 & 1.573 & $0 \cdot 062$ & $2 \cdot 76$ & $44 \cdot 52$ \\
\hline $\mathrm{Ni2}$ & $0 \cdot 562$ & $1 \cdot 585$ & 0.062 & $2 \cdot 87$ & $46 \cdot 29$ \\
\hline Ni3 & $0 \cdot 571$ & 1.590 & $0 \cdot 062$ & $3 \cdot 20$ & $51 \cdot 61$ \\
\hline $\mathrm{Ni} 4$ & $0 \cdot 579$ & 1.599 & $0 \cdot 062$ & $3 \cdot 30$ & $53 \cdot 23$ \\
\hline Ni5 & $0 \cdot 587$ & $1 \cdot 608$ & $0 \cdot 062$ & $3 \cdot 51$ & $56 \cdot 61$ \\
\hline $\mathrm{Co}^{2+}$ absorption & & & $\mathrm{Co}^{2+}$ & at $595 \mathrm{~nm}$ & $\varepsilon_{\mathrm{Co} 2+}$ \\
\hline Col & $0 \cdot 557$ & $1 \cdot 573$ & $0 \cdot 016$ & 2.44 & $152 \cdot 50$ \\
\hline $\mathrm{Co} 2$ & $0 \cdot 562$ & 1.585 & $0 \cdot 016$ & $2 \cdot 65$ & 165.63 \\
\hline $\mathrm{Co3}$ & $0 \cdot 571$ & 1.590 & $0 \cdot 016$ & $2 \cdot 80$ & $175 \cdot 00$ \\
\hline $\mathrm{Co} 4$ & $0 \cdot 579$ & $1 \cdot 599$ & $0 \cdot 016$ & $2 \cdot 95$ & $184 \cdot 38$ \\
\hline $\operatorname{Co} 5$ & $0 \cdot 587$ & $1 \cdot 608$ & $0 \cdot 016$ & $3 \cdot 09$ & $193 \cdot 13$ \\
\hline
\end{tabular}

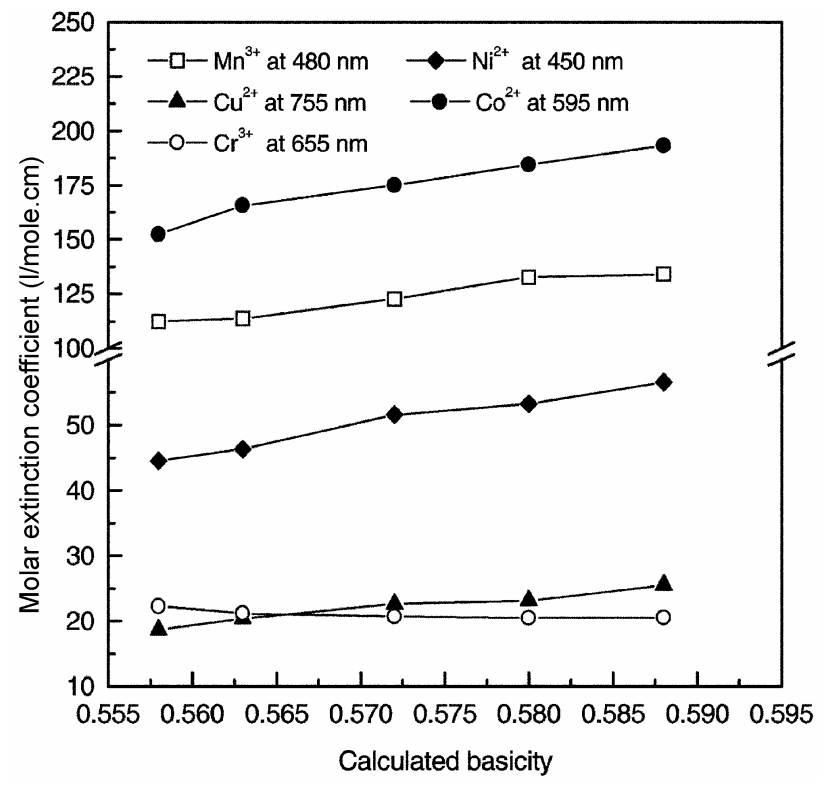

Figure 9. Maxima molar extinction coefficients of each ion in $1 /$ mole.cm at their maximum wavelength as a function of glass basicity.

\section{Conclusions}

The basicity of the experimental glasses increased due to increase in the $\mathrm{Na}_{2} \mathrm{O}$ concentration. The proportion of the NBOs was obtained. The NBOs caused the $Q^{4}$ species to depolymerize and transform to $Q^{3}$ species. These results were confirmed with the shift of broadening peaks of XRD patterns. The redox ratios of the $\mathrm{Mn}^{2+}-\mathrm{Mn}^{3+}, \mathrm{Cu}^{+}-$ $\mathrm{Cu}^{2+}$ and $\mathrm{Cr}^{3+}-\mathrm{Cr}^{6+}$ couples reduced due to the redox reactions which shifted toward their oxidized ions. While the $\mathrm{Ni}^{2+}-\mathrm{Ni}^{3+}$ and $\mathrm{Co}^{2+}-\mathrm{Co}^{3+}$ couples were assumed to be present only in the $\mathrm{Ni}^{2+}$ and $\mathrm{Co}^{2+}$ ions with increasing basicity in these glasses. The optical absorption bands of $\mathrm{Mn}^{3+}, \mathrm{Cu}^{2+}, \mathrm{Cr}^{3+}, \mathrm{Ni}^{2+}$ and $\mathrm{Co}^{2+}$ ions occurred at constant wavelengths with different optical densities or intensities. The increase in intensities of these absorbing ions, except for $\mathrm{Cr}^{3+}$ ion, at the maximum wavelength was affected by the increase of ion concentration and the molar extinction coefficient. These changes were evidenced through the increase in intensity of glass colours. Whereas in the case of $\mathrm{Cr}^{3+}$ ion, the results were opposite as the intensities depended strongly on the decrease of concentration. 


\section{Acknowledgements}

The authors gratefully acknowledge the financial support by The Commission on Higher Education, Ministry of Education, Thailand and the Graduate School, Chiang Mai University, Thailand.

\section{References}

Bamford C R 1962 Phys. Chem. Glasses 3189

Bamford C R 1977 Colour generation and control in glass (New York: Elsevier Scientific Publishing Company) pp $1-16$

Claes P and Decelle E 2001 J. Non-Cryst. Solids 28837

Conradt R 1997 in Fundamentals of glass science and technology (Glafo: The Glass Research Institute) p. 15

Dawy M and Salama A H 2001 Mater. Chem. Phys. 71137

Dimitrov V and Komatsu T 1999 J. Non-Cryst. Solids 249 160

Duffy J A 1996 J. Non-Cryst. Solids 19645

Duffy J A 2002 J. Non-Cryst. Solids 297275

Duffy J A and Ingram M D 2002 C.R. Chimie 5797
Jones A R, Winter R, Greaves G N and Smith I H 2001 J. NonCryst. Solids 293-295 87

Knowles A and Burgess C 1984 Practical absorption spectrometry (New York: Chapman and Hall) pp 14-16

Krämer F W 1991 Glastech. Ber. 6471

Matschat R, Dette A and Guadagnino E 2004 Final certification report of BAM-S004 (Berlin: Federal Institute for Materials Research) pp 1-21

Meneau F, Greaves G N, Winter R and Vaills Y $2001 \mathrm{~J}$. NonCryst. Solids 293-295 693

Müller-Simon H 1996 Glastech. Ber. 69387

Paul A 1990 Chemistry of glasses (London: Chapman and Hall) 2nd ed., pp 236-238

Paul A and Douglas R W 1995 Phys. Chem. Glasses 6212

Pyare R and Nath P 1982 J. Am. Ceram. Soc. 65549

Schreiber H D 1986 J. Non-Cryst. Solids 84129

Schreiber H D, Kochanowski B K, Schreiber C W, Morgan A B, Coolbaugh M T and Dunlap T G 1994 J. Non-Cryst. Solids 177340

Singh S P and Kumar A 1995 J. Mater. Sci. 302999

Singh S P, Tarafder Aman and Tarafder Anal 2004 Bull. Mater. Sci. 27281

Zhang P, Dunlap C, Florian P, Grandinetti P J, Farnan I and Stebbins J F 1996 J. Non-Cryst. Solids 204294 